\title{
Ultrastructural Features of Mitochondria-Rich Cells in Stenohaline Freshwater and Seawater Fishes
}

\author{
M. PISAM, G. BOEUF, P. PRUNET, AND A. RAMBOURG \\ Département de Biologie, Centre d'Etudes Nucléaires de Saclay, 91191 Gif sur Yvette, Cedex, France
}

\begin{abstract}
In order to elucidate the functional significance of accessory cells in freshwater fishes, such as the rainbow trout, which displays a poor adaptability to seawater life, a search for such cells was performed in two stenohaline freshwater fishes: the loach and the gudgeon. Accessory cells were never encountered in these species; but, in contrast, two types of chloride cells were observed consistently that strikingly resembled the $\alpha$ - and $\beta$-cells previously described in the guppy, a freshwater-adapted euryhaline fish. The $\alpha$-cell, a pale and elongated chloride cell, was located at the base of the secondary lamellae in close contact with the arterioarterial pillar capillary. Darker, ovoid chloride cells resembling the $\beta$-cell were found exclusively in the interlamellar region of the primary epithelium facing the central venous sinous. The latter cells frequently formed multicellular complexes linked together by deep, narrow, apical junctions.

In another experiment, a stenohaline seawater fish, the turbot, was adapted to diluted 5\% saltwater and to fresh water. In seawater, the gill epithelium contained only one type of chloride cell, always associated with accessory cells. Due to numerous cytoplasmic interdigitations between the accessory cells and the apical portion of the chloride cell, there was a noticeable increase in the length of the shallow apical junction, sealing off the intercellular space between the two cell types. In 5\% saltwater, there was a decrease in the number of these interdigitations and a concomitant decrease in the length of the shallow apical junction. In fresh water, chloride cells were partially or completely separated from the outside medium by modified accessory cells.

It is thus concluded that accessory cells are found exclusively in fish living in seawater or preadapted to seawater and that they probably are involved in the formation and modulation of paracellular pathways for ionic excretion. In contrast, the respective roles of the two types of chloride cells observed in freshwater fishes are still to be determined.
\end{abstract}

\section{INTRODUCTION}

Accessory cells are small mitochondria-rich cells commonly observed in the gill epithelium of seawater- adapted euryhaline fishes (Hootman and Philpott, 1980; Laurent and Dunel, 1980). They are always adjacent to the apical regions of large seawater chloride cells, to which they are interconnected by numerous, presumably short junctions. They are thought to have a role in ion excretion, and thus in maintaining the hydromineral balance of an animal living in a hyperosmotic environment (Sardet et al., 1979; Dunel-Erb and Laurent, 1980).

Accessory cells were also observed in the gill epithelium of freshwater-adapted euryhaline fishes such as the Atlantic salmon, Salmo salar. In this species, however, they made their appearance just before the migration of the fish into seawater and thus were thought to represent a preadaptation to seawater life (Pisam et al., 1988).

The presence of accessory cells in the gill epithelium of the juvenile rainbow trout Salmo gairdneri, which shows a poor adaptability to seawater life, was in contrast quite intriguing (Pisam et al., 1989) and raised the question of the functional significance of these cells in freshwater-adapted fishes.

To clarify the situation, we pursued our investigation in a twofold direction. First, a search for the presence of accessory cells was performed in the gill of freshwater stenohaline fishes. In two species-the loach and the gudgeon-accessory cells were never encountered; but two kinds of chloride cells were observed consistently, one of which could form multicellular complexes. Then the fate of accessory cells was followed in a marine fish - the turbot- which at a juvenile stage may be encountered in the diluted seawater of estuaries. When this fish was progressively transferred into diluted saltwater, the accessory cells did not disappear, but underwent ultrastructural modifications.

\section{MATERIALS AND METHODS}

Stenohaline freshwater fishes, i.e., gudgeons (Gobio gobio) of 77-mm average length and loaches (Cobitis taenia) of 118-mm average length, were taken from a river near Rennes, France.

Stenohaline marine fishes, i.e., turbots (Scophthalmus maximus) of $115-\mathrm{mm}$ average length were kept in laboratory holding tanks filled with seawater (i.e., 35\%o saltwater). Some fishes were progressively

Received May 3, 1989. Accepted July 28, 1989.

Address reprint requests to Dr. M. Pisam, Département de Biologie, CEN-Saclay, 91191 Gif-sur-Yvette Cedex, France. 
adapted to fresh water in the following way: they were maintained for 10 days in $20 \%$ saltwater, for 10 days in $10 \%$ saltwater, and for 4 days in $5 \%$ saltwater. Then they were transferred to freshwater ( $0 \%$ saltwater) in which they were kept for 2 days.

Gills were quickly dissected out and fixed for $1 \mathrm{hr}$ at room temperature in $2 \%$ glutaraldehyde buffered with $0.08 \mathrm{M}$ sodium cacodylate, $\mathrm{pH} 7.5$. Gill fragments then were postfixed for $1 \mathrm{hr}$ in $1: 1$ potassium ferrocyanide (3\%): osmium tetroxide (2\%) (Karnovsky, 1971), dehydrated, and embedded in Epon. Sections were stained for 2 min with lead citrate and examined at $80 \mathrm{kv}$ with a Philips EM 400 electron microscope.

The relative number of chloride and accessory cells in the gill epithelium of seawater and freshwateradapted turbots was estimated by counting, in three fishes for each physiological condition, the number of cells per interlamellar region. Cells were counted at the base of the filaments in sections running parallel to the long axis of the primary lamella and perpendicular to the secondary lamellae.

The surface areas of both cell types were measured on thin sections passing through the nucleus. They were calculated, from 12 cells of each type in each physiological condition, using a Kontron M15 image analyzer on micrographs enlarged to a final magnification of $\times 2,800$. Differences in numbers and surface areas of both cell types in seawater and freshwater conditions were assessed using the Student's $t$-test.

\section{RESULTS}

In all types of fishes, the gill consisted of several branchial arches bearing primary lamellae (or filaments) from which radiated the secondary lamellae. The primary and secondary lamellae are covered, respectively, by the primary and the secondary epithelia. The regions of the primary lamella separating the bases of adjacent secondary lamellae are referred to as interlamellar regions. These interlamellar regions are thus covered by the primary epithelium, which is continuous with the secondary epithelium at the base of each secondary lamella. Both types of epithelia included several types of cells, among which only the mitochondria-rich cells will be considered in this paper.

\begin{tabular}{ll}
\hline & \multicolumn{1}{c}{ ABBREVIATIONS } \\
A & accessory cell \\
am,AM & apical membrane \\
C & chloride cell \\
dC & dark chloride cell \\
er,ER & endoplamic reticulum \\
f & feltwork \\
j & junction \\
IC & light chloride cell \\
m,M & mitochondria \\
MB & membrane-bound bodies \\
n,N & nucleus \\
P & pavement cell \\
PC & pillar capillary \\
SW & saltwater \\
T & tubular system \\
VT & vesiculotubular system
\end{tabular}

\section{Mitochondria-Rich Cells in Two Freshwater Stenohaline Fishes: the Loach and the Gudgeon}

In the gill epithelium of both types of fishes, the mitochondria-rich cells had the appearance of the socalled chloride cells commonly encountered in the gills of freshwater-adapted fishes. They were large cells containing numerous mitochondria and an extensive tubular system made up by intracytoplasmic invaginations of the basolateral plasma membrane. The apical surface, in contact with the outside medium, was flattened and displayed a few microvilli. On the basis of their location and some additional ultrastructural features, these chloride cells could be separated into two classes: light and dark cells.

\section{Light cells}

These were pale, ovoid, and somewhat elongated cells located in the secondary epithelium or in the primary epithelium at the base of a secondary lamella. In the latter location (Fig. 1), a large portion of the basolateral surface was facing the pillar capillary. Their tubular system consisted of membranous tubules that were anastomosed to form an extended network with roughly polygonal meshes. This tubular network was distributed throughout the whole cytoplasm except for a narrow apical zone containing a few vesicles and tubules of the vesiculotubular system. The endoplasmic reticulum was made up of anastomosed and slightly dilated cisternae intercrossing the meshes of the tubular system (Figs. 1, 4).

Figs. 1-7. Chloride cells in the gill epithelium of the loach.

Fig. 1. The ovoid, elongated, light chloride cell is located at the base of a secondary lamella in close contact with the pillar capillary. $\times 4,000$.

Fig. 2. An isolated square, dark chloride cell may be seen between two pavement cells in the primary epithelium of an interlamellar region. $\times 4,000$.

Fig. 3. Two dark chloride cells are adjacent to each other in an interlamellar space. At lower left, note the flattened cisternae of endoplasmic reticulum in the perinuclear region. $\times 4,000$.

Fig. 4. At left, the light chloride cell contains numerous mitochondria and membranous tubules anastomosed in a loose network. The endoplasmic reticulum consists of anastomosed and slightly dilated cisternae. A few vesicles and tubules of the vesiculotubular system are seen in the apical region just below the wavy plasma membrane. At right, the apex of a dark chloride cell is filled with numerous large, irregular, membrane-bound bodies and has a slightly indented apical membrane. $\times 14,000$.

Figs. 5, 6. The apical junction (between parallel arrows) binding the apical portions of two chloride cells (Fig. 5) is as narrow and deep as the one observed between a pavement and a chloride cell (Fig. 6). $\times 39,000$.

Fig. 7. In the dark chloride cell, the relatively wide elements of the tubular system are frequently arranged in compact parallel arrays. $\times 13,000$ 

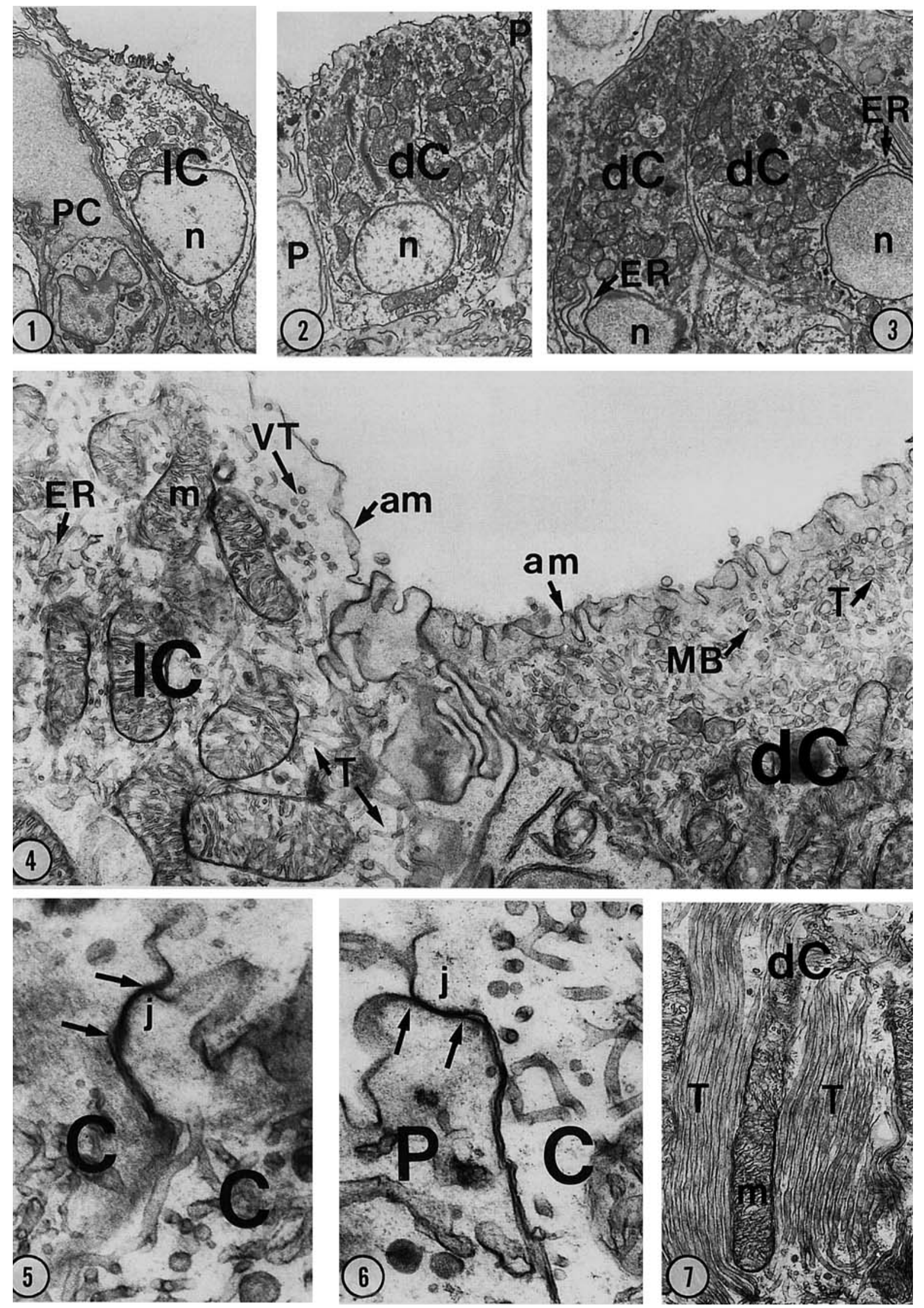

Figs. $1-7$ 

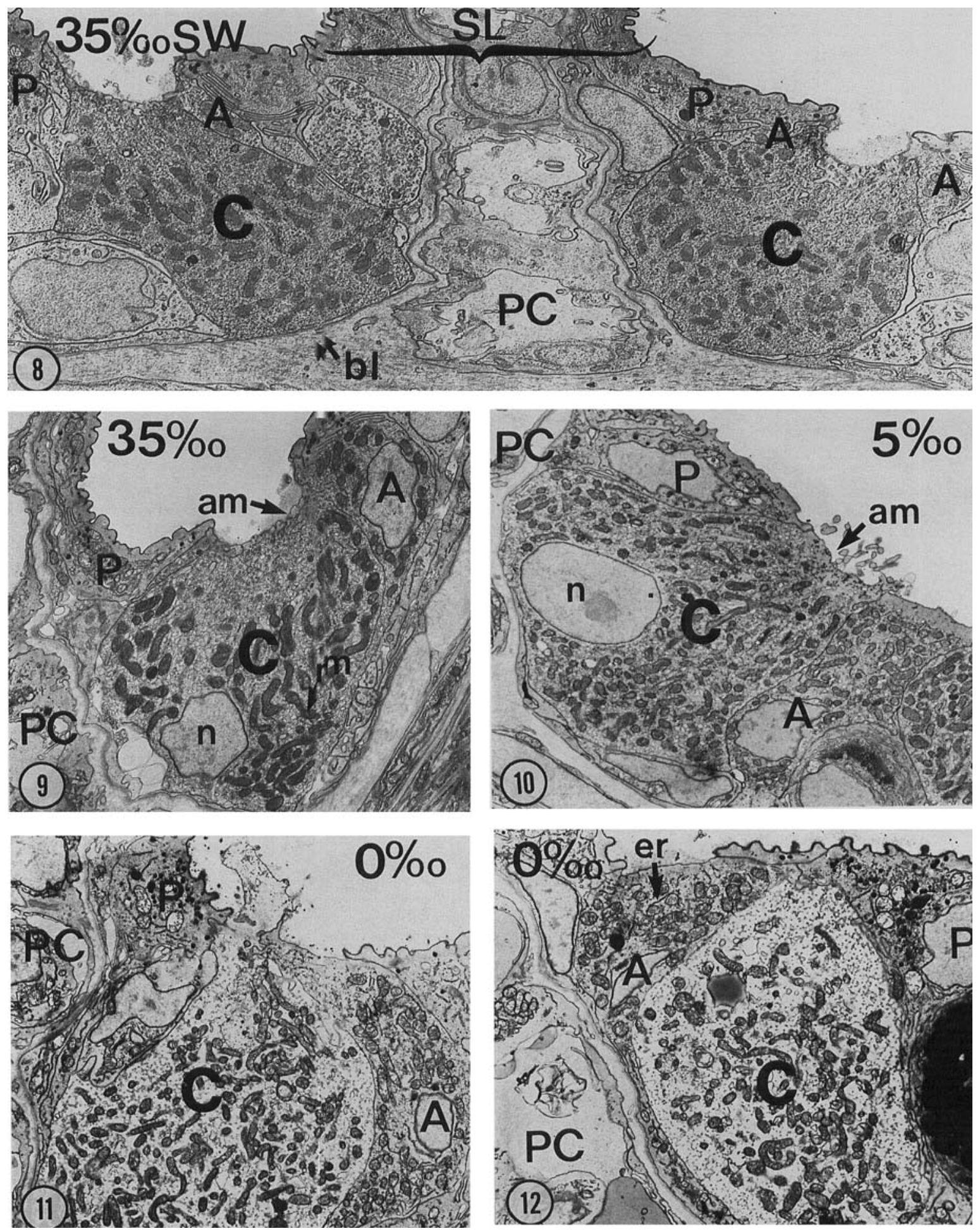

Figs. 8-12. 


\section{Dark cells}

These were found only in the primary epithelium of the interlamellar spaces, where they were isolated (Fig. 2) or formed multicellular complexes (Fig. 3). They were cuboidal (Fig. 2) or pear-shaped cells (Fig. 3 ), with the nucleus located in the lower third of the cytoplasm. The elements making up the tubular system were somewhat wider than in the light cells and had a tendency to form parallel arrays (Fig. 7). The endoplasmic reticulum was formed by long flattened cisternae, which were concentrated in the basal, perinuclear region (Figs. 2, 3). The characteristic ultrastructural feature of the dark cells, however, was the accumulation of numerous spheroidal membranebound bodies in the apical zone (Fig. 4).

In both freshwater stenohaline fishes, accessory cells, namely small mitochondria-rich cells, were never appended to the apical portion of either cell type. When dark cells formed multicellular complexes, all cells were of similar size (Fig. 3) and were bound together by deep, narrow, apical junctions $(350-400 \mathrm{~nm})$ similar to those observed between chloride and pavement cells (Figs. 5, 6).

\section{Mitochondria-Rich Cells in a Seawater Stenohaline Fish: The Turbot}

As in seawater-adapted fishes, the gill epithelium of the turbot contained only one type of chloride cell; but this type of cell always was associated with accessory cells (Figs. 8-18).

\section{Seawater-maintained fishes}

In fishes maintained in seawater, the chloride cells were encountered only in the primary epithelium of the interlamellar space. Like the light cells in freshwater fishes, they usually were located at the base of the secondary lamellae (Fig, 8). They were voluminous (Table 1) and cuboidal in shape (Figs. 8, 9). The tubular

Figs. 8-12. Chloride and accessory cells in the gill epithelium of the seawater turbot or in turbots adapted to diluted saltwater and freshwater.

Fig. 8. In the gill epithelium of this seawater turbot, two voluminous chloride cells are located on either side and at the base of a secondary lamella (SL). Their basolateral surface is in contact with the basal lamina (bl) of the primary epithelium, $\times 4,000$.

Fig. 9. In seawater (35\% SW), the cytoplasm of the large chloride cell and that of its smaller accessory cell display the same density. In the apical region, a large portion of the chloride cell is devoid of mitochondria. The depressed apical surface of the chloride cell and the flattened apex of the accessory cell form the wall of the apical cavity. $\times 4,200$.

Fig. 10. In 5\% saltwater, the apical surface of the chloride cell is no longer depressed but instead sends numerous projections in the outside medium; in contrast, the flattened apex of the accessory cell remains unaltered, $\times 4,200$

Figs. 11, 12. In freshwater (0\%o SW), the cytoplasm of the chloride cell is significantly paler than that of the accessory cell. The intercellular space between the two cell types is noticeably straight. In Figure 11 , the chloride cell sends a narrow apical projection in the outside medium; in Figure 12, this cell seems to be separated from the outside medium by the accessory cell. $\times \mathbf{4 , 2 0 0}$
TABLE 1. Mean surface areas (in $\mu \mathrm{m}^{2} \pm \mathrm{SD}$ ) of mitochondria-rich cells in sections of the primary gill epithelium from seawater or freshwater-adapted turbot ${ }^{1}$

\begin{tabular}{lccc} 
& $\mathrm{n}$ & Chloride cells* & Accessory cells* \\
\hline $\begin{array}{l}\text { Seawater } \\
\quad(35 \% \text { SW) }\end{array}$ & 12 & $120 \pm 30$ & $30 \pm 8$ \\
$\begin{array}{l}\text { Freshwater } \\
\quad(0 \% \text { SW })\end{array}$ & 12 & $162 \pm 49$ & $55 \pm 19$ \\
$t$-test & & $P<0.025$ & $P<0.001$ \\
\hline
\end{tabular}

${ }^{1} \mathrm{n}=$ number of cells.

*Difference between seawater and freshwater is significant.

system consisted of slightly distended, membranous tubules that formed an extensive network with small regular polygonal meshes; the meshes were frequently penetrated by cisternae of the endoplasmic reticulum (Fig. 13). Numerous mitochondria were distributed uniformly throughout the cytoplasm, except in the apical region, which contained the numerous vesicles and tubules of the vesiculotubular system (Pisam, 1981) (Figs. 13, 14). The apical plasma membrane facing the external medium was depressed to form an apical cavity filled with a filamentous feltwork (Fig. 13).

The apical portion of the chloride cell was linked to the adjacent accessory cells by shallow junctions (about $25 \mathrm{~nm}$ in length), which contrasted with the deep and narrow junctions (about $300 \mathrm{~nm}$ in length) binding chloride (or accessory) cells to adjacent pavement cells (Fig. 14). The basal surface of the chloride cell was always in contact with the basement membrane of the primary epithelium.

The accessory cells were small mitochondria-rich cells (Table 1) adjacent to the apical portion of the chloride cells. They remained located in the superficial regions of the primary epithelium and thus never reached its basal lamina (Fig. 8). They sent into the apex of the chloride cells numerous interdigitations, which usually reached the outside medium. As a result, the wall of the cavity at the apex of the chloride cells consisted of parts of the apical surface of the latter cells interlocked with numerous apical processes of accessory cells by shallow apical junctions (Fig. 13). The margins of this cavity, however, were usually formed by flattened apical surfaces of the accessory cells (Figs. $8,9,13,14)$. Except for the apical region, which was almost devoid of vesiculotubular elements (Figs. 13, 14), the cytoplasm of the accessory cells resembled that of the chloride cells and showed a similar density (Fig. 13). It contained an extensive tubular network in which membranous tubules formed a tight system of small regular polygonal meshes intercrossed by cisternae of the endoplasmic reticulum.

\section{Adapted to $5 \%$ saltwater}

In fish adapted to $5 \%$ saltwater, the size of the chloride cells was not modified (Fig. 10). Except for elements of the tubular system, which seemed to be less dilated (Fig. 15), the overall appearance of the cytoplasm remained unaltered. In contrast, the apical surface was no longer depressed to form an apical cavity 

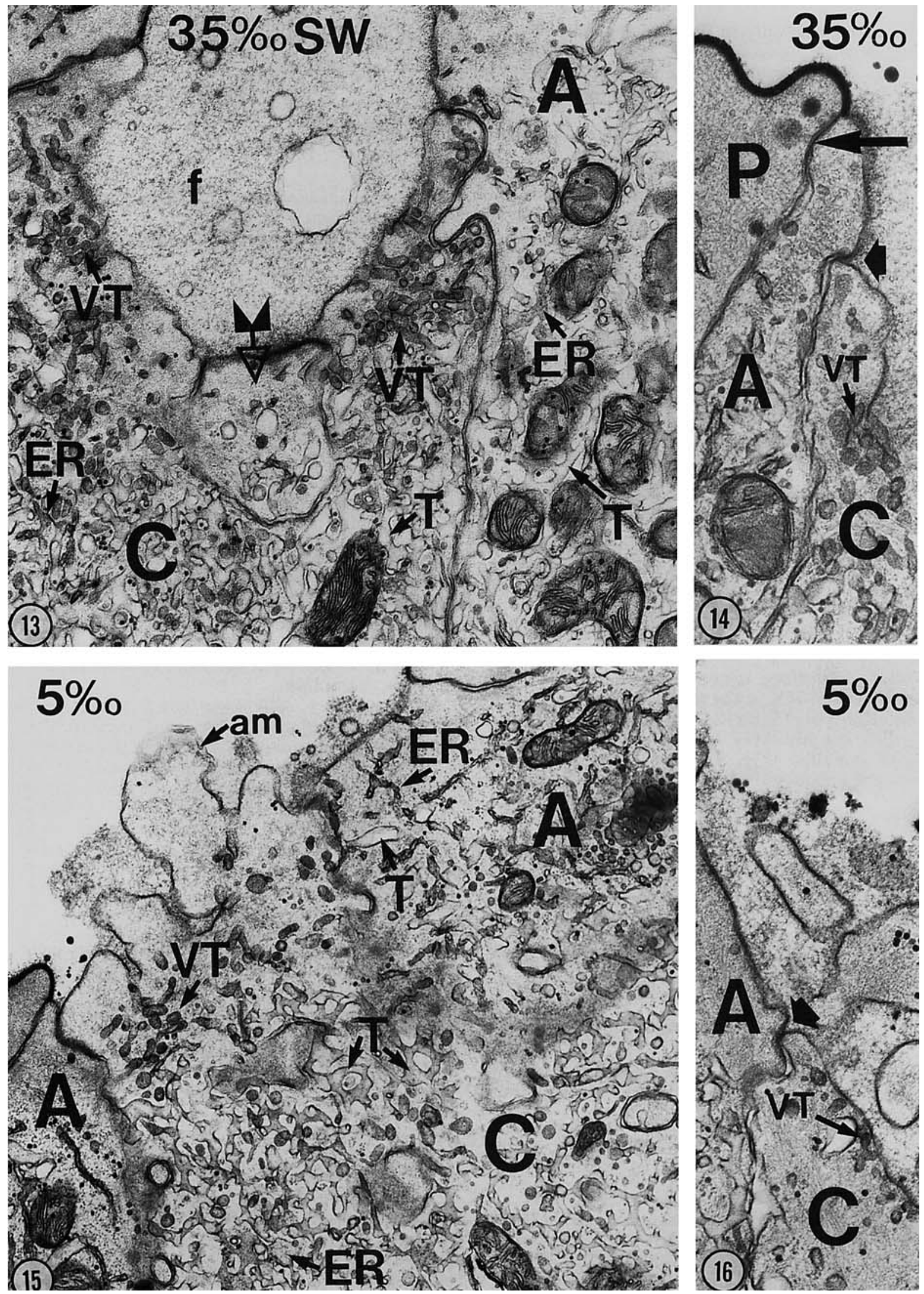
TABLE 2. Mitochondria-rich cell numbers (mean \pm S.D.) in interlamellar region of primary gill epithelium from seawater and freshwater-adapted turbot ${ }^{1}$

\begin{tabular}{|c|c|c|c|c|}
\hline & $\mathbf{n}$ & $\begin{array}{c}\text { Chloride } \\
\text { cells* }\end{array}$ & $\begin{array}{c}\text { Accessory } \\
\text { cells* }\end{array}$ & $\begin{array}{c}\text { Inter- } \\
\text { digitations } \\
\text { between } \\
\text { chloride } \\
\text { cells and } \\
\text { accessory cells }\end{array}$ \\
\hline $\begin{array}{l}\text { Seawater } \\
(35 \% \circ \mathrm{SW})\end{array}$ & 40 & $1.57 \pm 0.49$ & $1.55 \pm 0.49$ & $3.87 \pm 1.23$ \\
\hline $\begin{array}{l}\text { Freshwater } \\
(0 \% \text { SW) } \\
\text { t-test }\end{array}$ & 40 & $\begin{array}{c}1.28 \pm 0.45 \\
P<0.01\end{array}$ & $\begin{array}{c}1.05 \pm 0.55 \\
\mathrm{P}<0.001\end{array}$ & 0 \\
\hline
\end{tabular}

${ }^{1} \mathrm{n}=$ number of intermellar regions.

*Difference between seawater and freshwater is significant.

but instead sent numerous protrusions into the external medium (Figs. 10, 15).

The accessory cells were still present and bound to the apical portions of chloride cells by shallow junctions (Fig. 16). However, the number of cytoplasmic interdigitations between the two cell types was reduced, and the intercellular space between them was less contorted than in seawater.

\section{Adapted to freshwater}

In freshwater-adapted fishes, both the chloride cells and accessory cells increased in size (Table 1) but decreased in number (Table 2). The accessory cells, however, remained smaller than the chloride cells (Table 1). In addition, both cell types underwent ultrastructural modifications.

Figs. 13-16. Apical portions of chloride and accessory cells in the gill epithelium of turbots adapted to $35 \% 0$ and $5 \%$ saltwater.

Fig. 13. In seawater ( $35 \%$ SW), an accessory cell sends an interdigitation (arrow) into the apical portion of the chloride cell. It reaches the outside medium and is thereby involved in the wall of the apical cavity, which is filled with a filamentous feltwork. In contrast to the accessory cell, the chloride cell displays in its apical region numerous elements of the vesiculotubular system. In both cells, the membranous tubules of the tubular system are conspicuous and intermingled with cisternae of the endoplasmic reticulum. $\times 25,000$.

Fig. 14. In seawater, the apical junction between the accessory cell and the chloride cell (arrowhead) is significantly shallower than the one between pavement and accessory cells (arrow). Note the presence of numerous vesiculotubular elements in the chloride cell. $\times 39,000$.

Fig. 15. In the gill epithelium of this 5\%o-saltwater-adapted fish, a chloride cell is sandwiched between two accessory cells. Its apex protrudes into the outside medium and contains elements of the vesiculotubular system. In contrast, the apex of the accessory cell at right remains flattened. It is devoid of any vesiculotubular elements and contains instead cisternae of endoplasmic reticulum. In both cell types, the tubular system is still prominent and consists of tightly anastomosed membranous tubules. $\times 25,000$.

Fig. 16. In 5\%o saltwater, a shallow junction (arrowhead) may still be observed between the apex of the accessory cell at upper left, and that of the chloride cell, at lower right. Note the vesiculotubular elements below the apical surface of the chloride cell. $\times 39,000$.
The cytoplasm of the chloride cells was significantly paler than in seawater (Figs. 11, 12, 17, 18). The tubular system contained narrower elements anastomosed into a looser network with irregular meshes (Figs. 17, 18). The mitochondria showed a tendency to gather in the perinuclear region, and some regions of the cytoplasm appeared to be completely devoid of organelles (Fig. 18). The apex of the cells either protruded into the outside medium or, frequently, was partially or completely separated from it by an accessory cell (Figs. 11, 12).

The cytoplasm of the accessory cells was denser than that of the chloride cells but paler than in seawater (Figs. 11, 12). In contrast to chloride cells, the flattened apical surface was often in contact with the outside medium. The tubular system was less developed, and large cytoplasmic areas were left in which flattened cisternae of the endoplasmic reticulum were clearly delineated (Figs. 11, 12). The accessory cells sent a few interdigitations into the chloride cells. These interdigitations, however, never reached the outside medium. As a result, apical junctions between the two cell types were difficult to find (Table 2).

\section{DISCUSSION}

In two freshwater stenohaline fishes, the loach and the gudgeon, two types of chloride cells were present, the light and the dark cells; these displayed, respectively, the same ultrastructural features as the $\alpha$ - and $\beta$-cells depicted by Pisam et al. (1987) in the gills of a freshwater-adapted euryhaline fish: Lebistes reticulatus. Like the $\alpha$-cells, the light cells located at the base of the secondary lamellae were in close contact with the arterioarterial capillaries; the dark cells, like the $\beta$ cells, located in the interlamellar space were facing only the central venous sinous (Fig. 19). These observations confirm the existence in freshwater fishes of at least two types of chloride cells, related respectively, to the arterial and venous blood compartments. However, as pointed out by Pisam et al. (1987), the roles of these cell types in the mechanism of ion exchange in the gill of freshwater fishes remain to be established.

In both freshwater stenohaline fishes, the dark cells showed a tendency to form multicellular complexes. This confirms the work of others (Lacy, 1983; Karnaky, 1986; Hwang, 1988) which showed that the presence of such complexes is not restricted to gills of seawateradapted fishes as was previously reported (Sardet et al., 1979; Laurent and Dunel, 1980). In contrast to Hwang's observations (1988) in three freshwater teleosts, and in keeping with data reported in parrs of the Atlantic salmon (Pisam et al., 1988), the dark cells in the loach and the gudgeon were bound together by deep and narrow apical junctions resembling the tight junctions described between neighboring pavement cells or between adjacent pavement and chloride cells. The formation of these multicellular complexes was thus not involved in the creation of paracellular pathways as is the case in the gill of seawater-adapted fishes (Sardet et al., 1979). Furthermore, accessory cells and the typical shallow junctions linking them to chloride cells were never encountered in the two freshwater fishes examined in the present study. It is concluded, then, that the structure of the gill epithelium in these two 

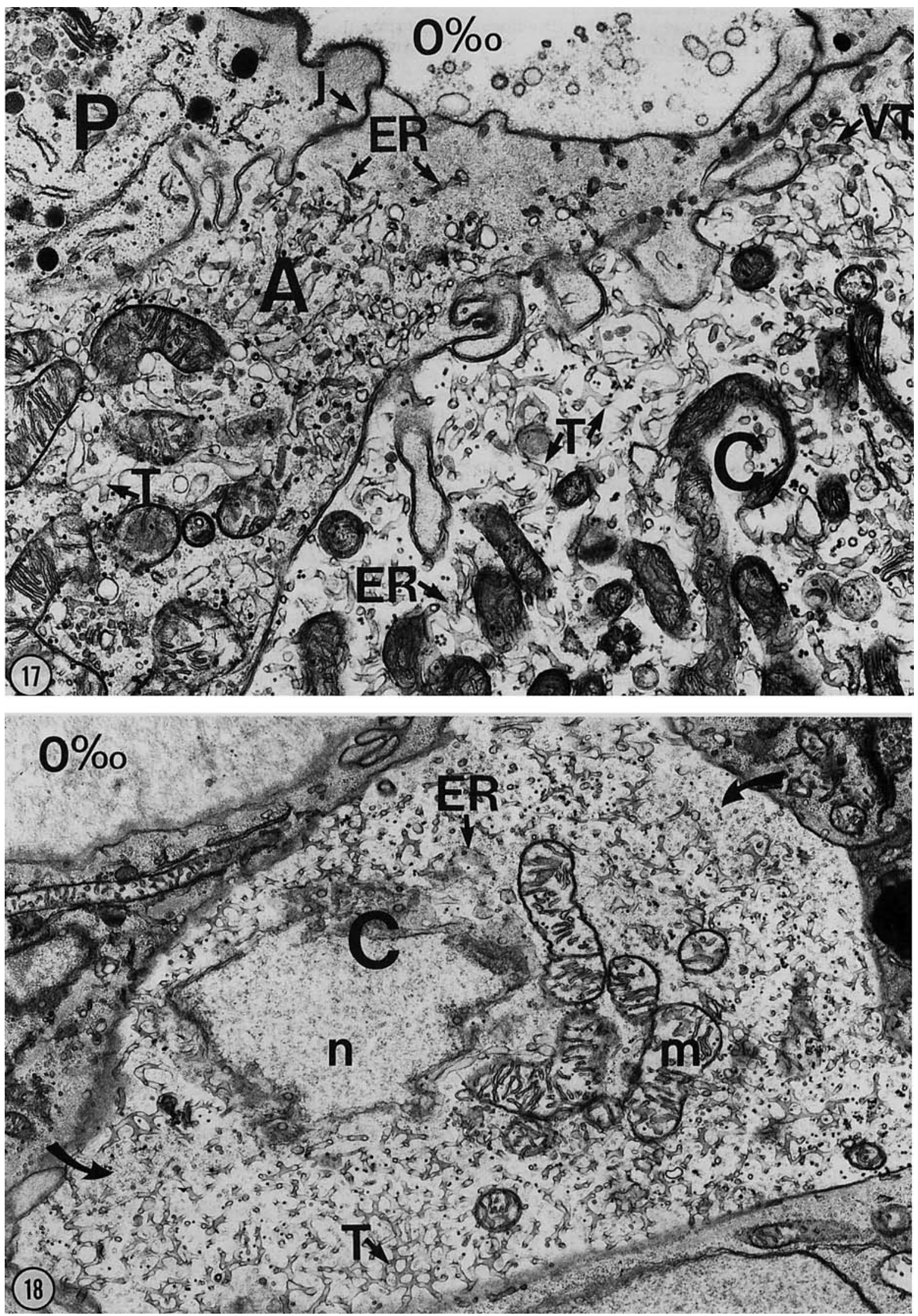
freshwater stenohaline fishes reflects the fact that they osmoregulate in a hypoosmotic environment and consequently do not need to excrete ions at the level of their gills.

The gill epithelium of the turbot, the seawater stenohaline fish, displayed the ultrastructural features characteristic of fishes well adapted to their seawater environment. There was only one type of chloride cell; it was associated with accessory cells by numerous cytoplasmic interdigitations which increased the length of the intercellular space between the two cell types (Fig. 19). As a result, there was a concomitant amplification of the length of the shallow junction that sealed off the apical part of this expanded intercellular space. As usually postulated, the shallow, presumably leaky junction which in face view displayed a marked tortuosity might provide a paracellular pathway allowing the fish to excrete ions into a hyperosmotic outside medium (Sardet et al., 1979; Ernst et al., 1980).

When the turbot was transferred into 5\%o saltwater, the accessory cells did not disappear and were still linked to chloride cells by shallow junctions (Fig. 19), as also reported by Hwang and Hirano (1985), in the gills of juvenile flounders adapted to $15 \%$ saltwater. There was, however, a significant decrease in the length of the shallow junction which sealed off the apical portion of a poorly convoluted intercellular space. Thus, this seawater stenohaline fish is able to adapt itself to diluted seawater and to respond by specific ultrastructural modifications to environmental conditions that it may, in fact, encounter in its juvenile stage in the water of river estuaries. The decrease in length of the shallow apical junctions is in keeping with the fact that a fish placed in a hypo-osmotic medium should limit its ionic excretion at the level of its gills. The persistence of accessory cells, in these conditions, might indicate in contrast that, the sojourn of the turbot in such water being temporary, specific structures have to be maintained to permit the formation of new paracellular pathways and facilitate a quick adaptation of the fish to full-strength seawater.

Variations on the theme have indeed already been observed in freshwater fishes that enter seawater at a later period of their life. In the juvenile freshwater rainbow trout, for instance, accessory cells were linked to chloride cells by apical junctions significantly shallower than those binding chloride and pavement cells. Transfer of this fish into seawater induced a further shallowing of these junctions, whereas the accessory cells sent numerous interdigitations into the apical portion of adjacent chloride cells (Pisam et al., 1989). Thus, although the trout at this stage of its life was not really prepared to enter a hyperosmotic medium, the transfer into seawater triggered the completion of ultrastructural transformations, allowing survival in such conditions. In contrast, the gill epithelium of freshwater smolts of the Atlantic salmon spontaneously displayed in freshwater the same characteristic features. It was postulated that these freshwater smolts were fully and spontaneously preadapted to seawater life.

In fresh water, the gill epithelium of the turbot exhibited ultrastructural features reflecting the difficulty, or perhaps the impossibility, for this seawater stenohaline fish to face such unphysiological conditions. The loss of any contact between chloride cells and the outside medium and the concomitant disappearance of apical junctions might indicate the shutoff of all excretory pathways to prevent any further leakage in such a hypo-osmotic environment. An interesting point, however, was that even in these drastic conditions the accessory cells, although deeply modified, did not disappear.

From these observations, it is suggested that accessory cells are a permanent feature of seawater stenohaline fishes. They are found exclusively in marine fishes or in fishes preadapted to seawater life where they are associated with chloride cells in a single functional unit. Variations in the depth and length of the junction sealing off the apical part of the more or less convoluted space between chloride and accessory cells allow the fish to withstand limited changes in water salinity, presumably by modulating the ionic excretion at the level of its gills.

\section{ACKNOWLEDGMENTS}

The drawing (Fig. 19) was prepared by M. Lucarain.

Figs. 17, 18: Chloride and accessory cells in the gill epithelium of a freshwater (0\%, SW)-adapted turbot.

Fig. 17. An accessory cell, bound to adjacent pavement cells by deep and narrow apical junctions, covers a large chloride cell and separates it from the outside medium. Its cytoplasm, denser than that of the chloride cell, contains numerous and relatively flattened cisternae of endoplasmic reticulum. Its tubular system is less developed than in seawater and consists of slightly dilated membranous tubules. In the chloride cell, endoplasmic reticulum elements are barely visible. The loosely anastomosed and narrow membranous tubules of the tubular system stand out sharply against the pale background. $\times 25,000$.

Fig. 18. In this somewhat altered chloride cell, a few swollen mitochondria are seen to be grouped in the juxtanuclear region. The membranous tubules of the tubular system are irregularly anastomosed, and several cytoplasmic areas seem to be deprived of cell organelles (arrows). $\times 15,000$. 


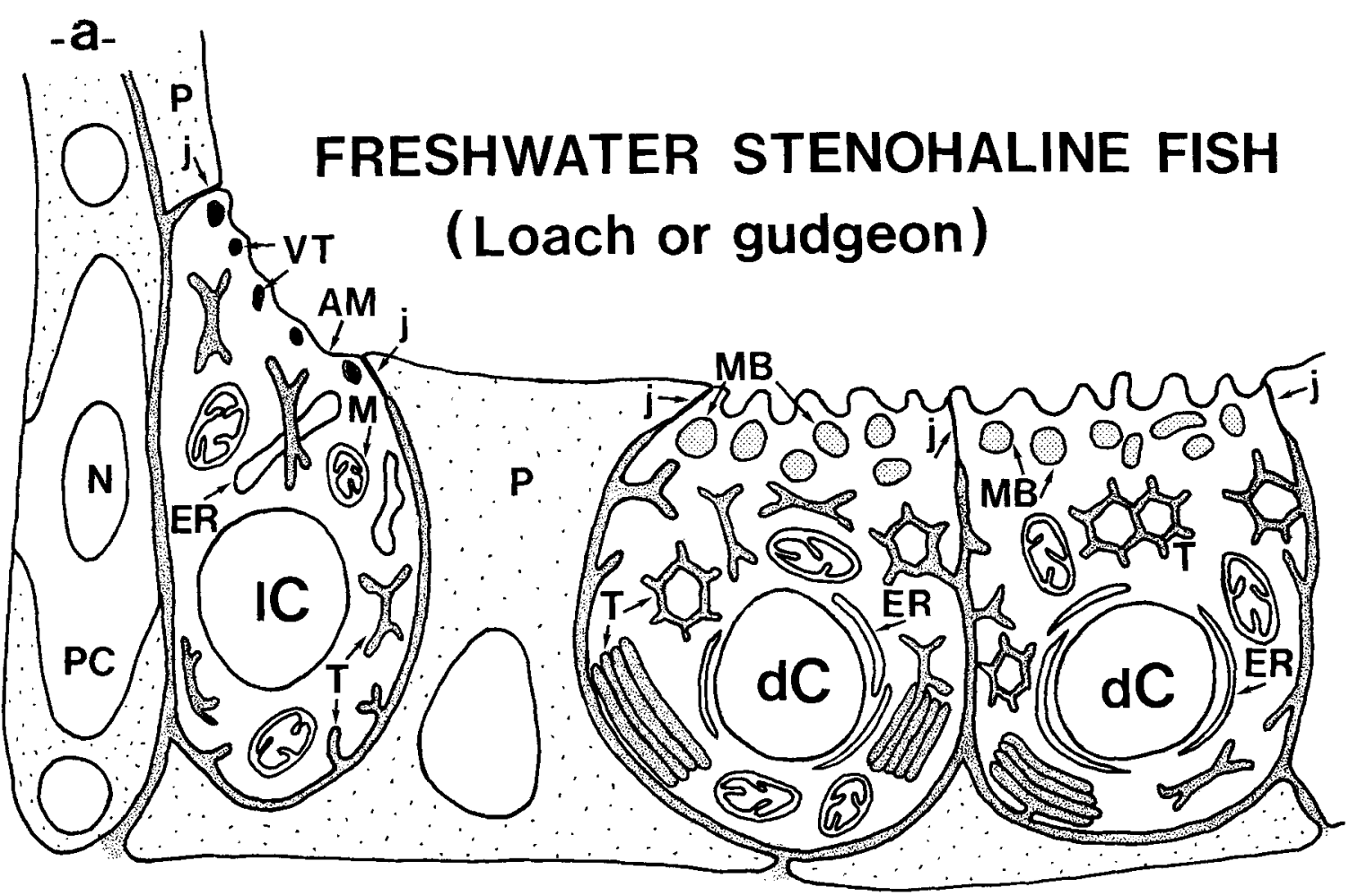

SEAWATER STENOHALINE FISH

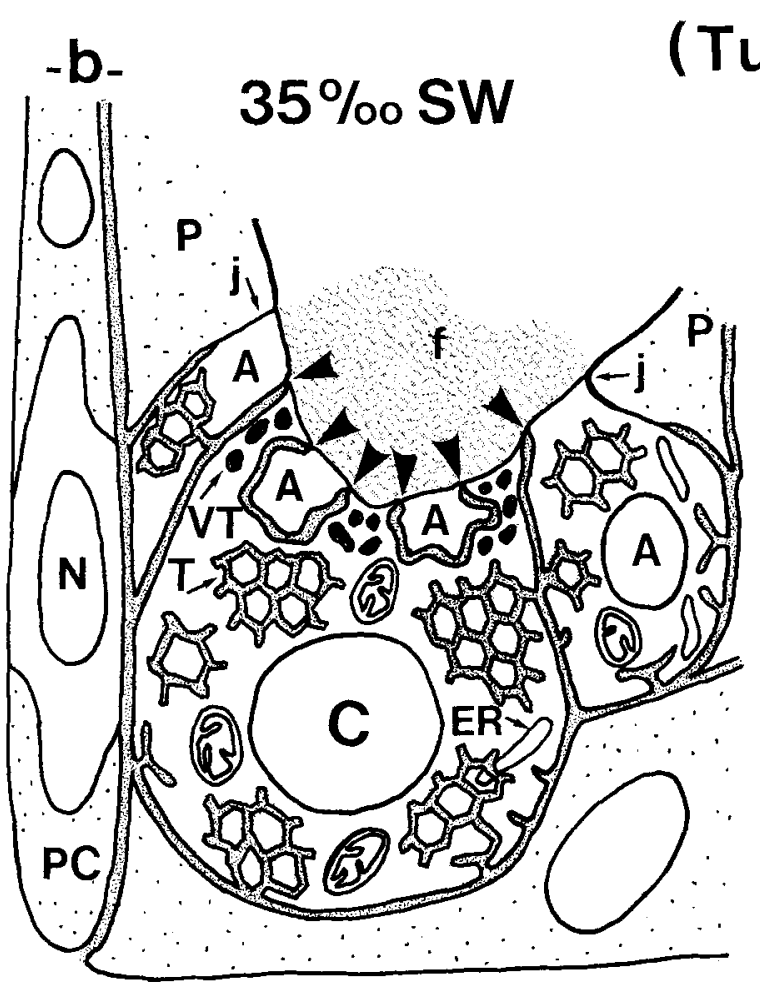

(Turbot) $5 \% \mathrm{SW}$

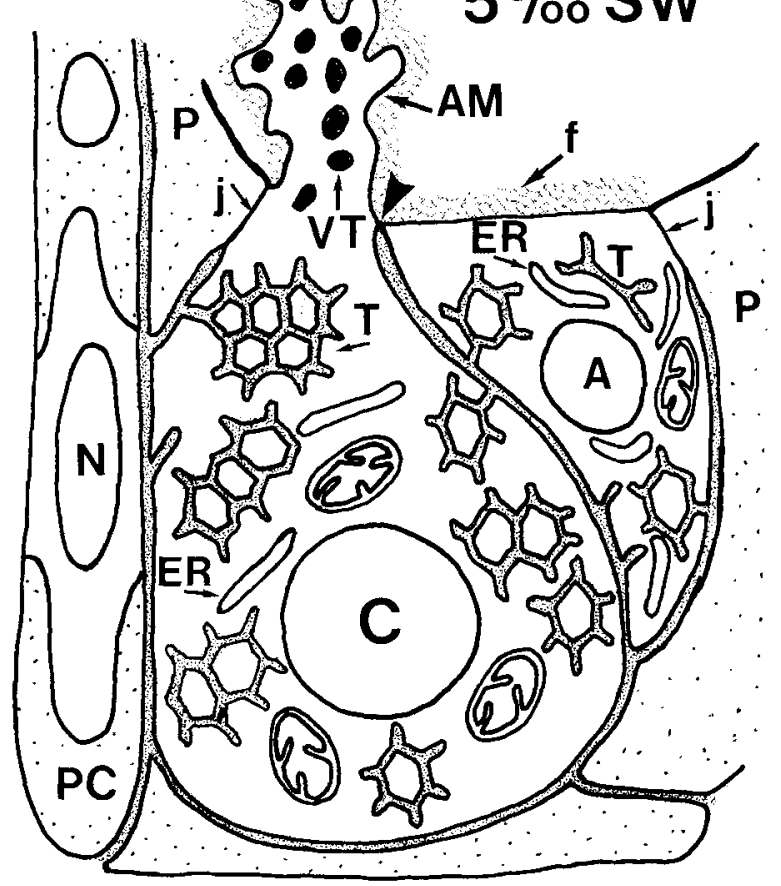

(19) 


\section{LITERATURE CITED}

Dunel-Erb, S., and P. Laurent 1980 Ultrastructure of marine teleost gill epithelia: SEM and TEM study of the chloride cell apical membrane. J. Morphol., 165:175-186.

Ernst, S.A., W.C. Dodson, and K.J. Karnaky 1980 Structural diversity of occluding junctions in the low resistance chloride secreting opercular epithelium of seawater adapted killifish (Fundulus heteroclitus) J. Cell Biol., 87:488-497.

Hootman, S.R., and C.W. Philpott 1980 Accessory cells in teleost branchial epithelium. Am. J. Physiol, 238:R199-R206.

Hwang, P.P., and R. Hirano 1985 Effects of environmental salinity on intercellular organization and junctional structure of chloride cells in early stages of teleost development. J. Exp. Zool., 236: $115-126$.

Hwang, P.P. 1988 Multicellular complex of chloride cells in the gills of freshwater teleosts. J. Morphol., 196:15-22.

Karnaky, K.J. 1986 Structure and function of the chloride cell of Fundulus heteroclitus and other teleosts. Am. Zool., 26:209-224.

Karnovsky, M.J. 1971 Use of ferrocyanide reduced osmium tetroxide in electron microscopy. Proc. 11th Am. Soc. Cell Biol., New Orleans, Abstract 284, p. 146.
Lacy, E.R. 1983 Histochemical and biochemical studies of carbonic anhydrase activity in the opercular epithelium of the euryhaline teleost, Fundulus heteroclitus. Am. J. Anat., 166:19-39.

Laurent, P., and S. Dunel 1980 Morphology of gill epithelia in fish. Am. J. Physiol., 238:R147-R159.

Pisam, M. 1981 Membranous systems in the chloride cell of teleostean gill: their modifications in response to the salinity of the environment. Anat. Rec., 200:401-414.

Pisam, M., A. Caroff, and A. Rambourg 1987 Two types of chloride cells in the gill epithelium of a freshwater-adapted euryhaline fish: Lebistes reticulatus; their modifications during adaptation to salt water. Am. J. Anat., 179:40-50.

Pisam, M., P. Prunet, G. Boeuf, and A. Rambourg 1988 Ultrastructural features of chloride cells in the gill epithelium of the Atlantic salmon, Salmo salar, and their modifications during smoltification. Am. J. Anat., 183:235-244.

Pisam, M., P. Prunet, and A. Rambourg 1989 Accessory cells in the gill epithelium of the freshwater rainbow trout Salmo gairdneri. Am. J. Anat., 184:311-320.

Sardet, C., M. Pisam, and J. Maetz 1979 The surface epithelium of teleostean fish gills. J. Cell Biol., 80:96-117.

Fig. 19. Diagrammatic representation of the ultrastructural features of mitochondria-rich cells in gills of freshwater and seawater stenohaline fishes. a: Gill of a freshwater stenohaline fish (loach or gudgeon). At left, an elongated light chloride cell is in close contact with the pillar capillary of a secondary lamella. A few vesiculotubular elements are seen just below its waved apical plasma membrane. Slightly dilated cisternae of endoplasmic reticulum intersect the loosely anastomosed membranous tubules of the tubular system. At right, two cuboidal dark chloride cells form a cellular complex in the interlamellar region. Numerous large, spheroidal membrane-bound bodies accumulate below the slightly indented apical surface. Flattened cisternae of endoplasmic reticulum are located predominantly in the perinuclear region. Along the basolateral surface, dilated elements of the tubular system form characteristic parallel arrays. Both types of chloride cells are bound together or to the adjacent pavement cells by deep and narrow apical junctions. b: Gill of a seawater stenohaline fish (turbot). In either normal strength (left) or in diluted seawater (right), a single type of chloride cell is always associated with accessory cells. It is a voluminous cell, cuboidal in shape, usually located at the base of a secondary lamella. Its apical region is filled with numerous vesiculotubular elements; the rest of the cytoplasm contains an extensive tubular system with numerous small polygonal meshes, frequently penetrated by cisternae of endoplasmic reticulum. In $35 \% \mathrm{SW}$, the apical surface of the chloride cell is depressed to form an apical cavity filled with a filamentous feltwork. In $5 \% \mathrm{SW}$, it sends instead numerous protrusions into the external medium. Always located adjacent to the apical portions of the chloride cells, the small accessory cells display a flattened apical surface and an apical region usually devoid of vesiculotubular elements. In $35 \%$ SW, the apical portions of the chloride and accessory cells are highly interdigitated. As a result, the apex of the chloride cell forms with its associated accessory cells a mosaic of cell processes linked together by a tortuous shallow junction (arrowheads). In $5 \%$ SW, the apices of chloride and accessory cells are poorly interdigitated, if at all; and a relatively short shallow junction is seen to seal off the apical portion of the straight intercellular space (arrowhead). In full strength or in diluted seawater, the cell complex formed by a chloride cell and its accessory cells is bound to adjacent pavement cells by deep and narrow apical junctions. 